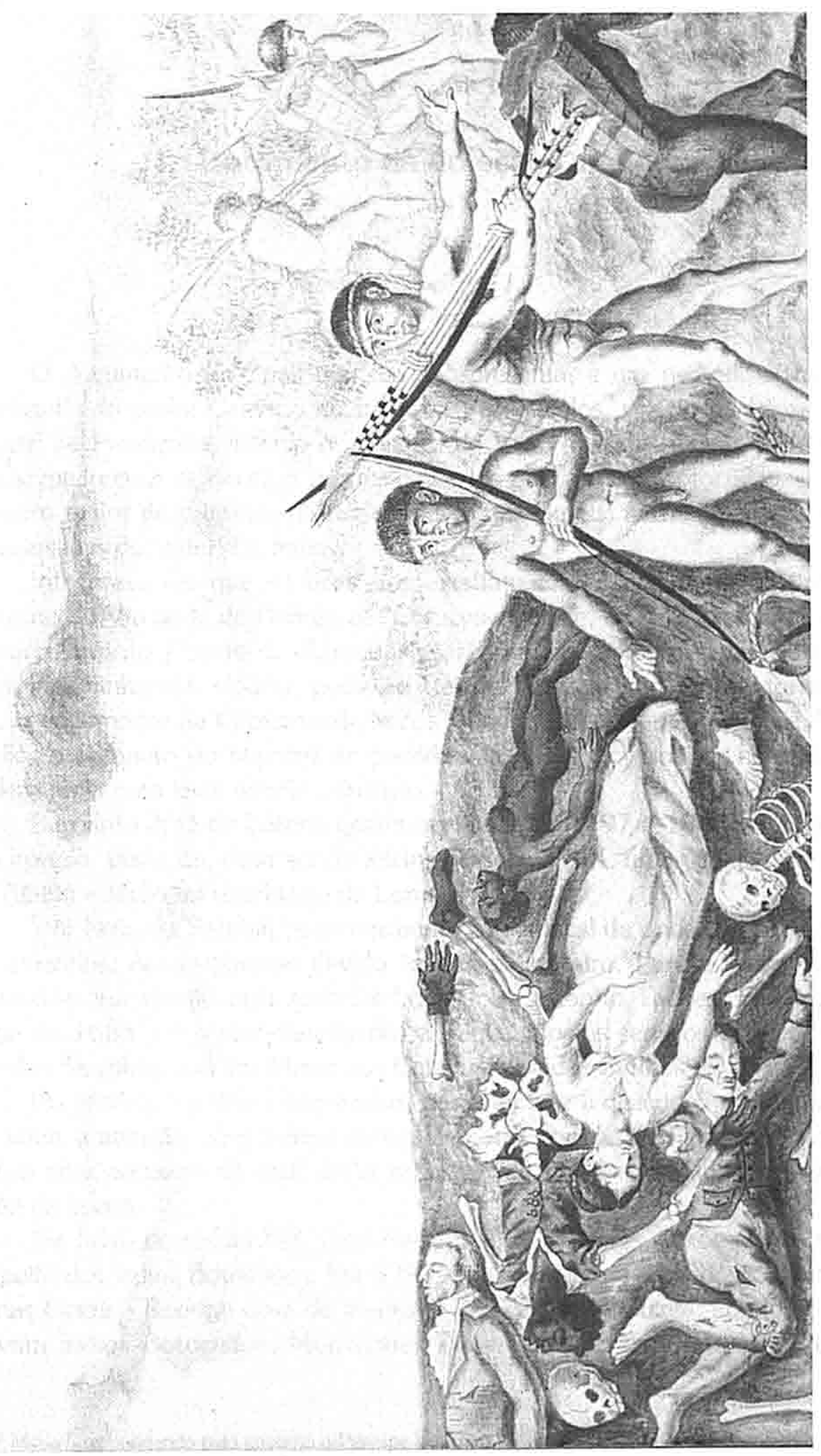

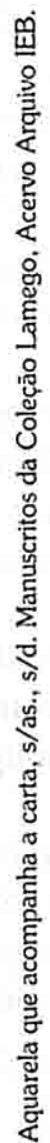




\section{Documento da Coleção Lamego}

O documento (original) que ora se apresenta, é um pedido, à Rainha de Portugal*, do padre Caetano da Fonseca Vasconcelos, vigário da Igreja de São Miguel de Piracicaba, situada no Distrito de Vila Nova da Rainha (atual Caeté). Preocupado com os danos e mortes causados pelos indios Botocudos, pedia um número maior de presídios na região das Minas Gerais, numa tentativa de evitar as investidas dos referidos índios.

Informava ele que os presídios existiam em maior número quando do govemo do Visconde de Barbacena. O sucessor deste, ou seja, Bemardo José de Lorena, quinto Conde de Sarzedas, restringiu o número desses presídios. Portanto, vinha ele, vigário, pedir ao Rei de Portugal para que autorizasse ao então govemador da Capitania de Minas Gerais, Pedro Maria Xavier de Ataíde e Mello, o aumento do número de presídios já que o govemador necessitava da ordem régia para levar avante o intento.

Bemardo José de Lorena govemou Minas de 1797 a 1803. O documento em apreço, portanto, deve ser de inícios do século XIX, uma vez que, o govemo de Ataíde e Mello foi ulterior ao de Lorena.

Vila Nova da Rainha, posteriormente Caeté,local de onde provinha o padre Vasconcelos, desenvolveu-se devido às jazidas de ouro. Parece que o primeiro sertanista que atingiu essa zona foi Lourenço Castanho Taques. Em uma carta régia de 1664, há o reconhecimento a Taques "pelos serviços prestados como um dos descobridores das Minas dos Cataguases e dos Sertöes de Caeté".

No escrito, o padre Vasconcelos, para reforçar a descrição e, provavelmente, atrair a atenção do govemo português para a questāo dos índios Botocudos, anexa uma aquarela na qual estāo representados costumes indígenas, segundo visão da época.

Em finais do século XIX, José Pedro Xavier da Veiga deixou alguns dados a respeito dos índios Botocudos. Em 1781, relatando sobre a ida do govemador de Minas Gerais - Rodrigo José de Menezes - ao sertão de Cuieté, aonde se encontravam indios Botocudos, Monsenhor Pizarro dizia: "Expondo-se portanto o

- D' Maria l, respondendo pelo governo o Príncipe D. Joāo. 
general às ciladas dessa gentilidade antropófaga, e rebelde, chegou no dia 16 de agosto de 1781 à nova ponte do Rio Doce (única paragem por onde se passa a tão dilatado Sertão); e sem atender a notáveis perigos no trajeto de rios e ribeirōes, a freqủentes encomodos nas subidas de ásperas e altas serras, a pé, e a repetidas faltas de sustento, foi ao sítio indicado de Cuyaté, onde havia uma aldeia de Índios domesticados à sombra do Presidio, e horrorizados do Botocudo...".

No ano de 1808, em carta régia, expedida ao governador do Espírito Santo, era ordenado que fomentasse a navegação no Rio Doce e fizesse abrir estradas pelo sertão adentro, tendo como finalidade o estabelecimento de comunicaçōes com a capitania de Minas Gerais. Com relaçāo ao desenvolvimento da navegaçāo no Rio Doce eram dadas ordens para que se procurasse submeter os indios Botocudos, fosse pela persuasão, fosse pela força, visto que os ditos indios devastavam aquela região, conforme então se afirmava.

Por outro lado, nesses anos inicias do século XIX, havia um interesse muito grande, por parte da corte - entāo estabelecida no Rio de Janeiro - em ver esses indios, tanto assim, que o governador de Minas Gerais recebeu a incumbência de enviar para lá alguns individuos pertencentes ao dito grupo "pela curiosidade que há de se ver essa raça antropófaga". Com relação aos indios Botocudos que foram mandados para o Rio de Janeiro, o governador de Minas Gerais recebeu a informaçāo de "ter o príncipe regente tido muito gosto em ver a índia botocuda $e$ seus dois filhos, que foram remetidos dessa Capitania".

Chabert referindo-se aos costumes dos Botocudos na década de 20 do século XIX, dizia apresentarem eles grande destreza ao atirar suas flechas, as quais, em geral, tinham as pontas envenenadas. Esses índios, observava Chabert, só nāo colocavam veneno nas flechas quando pretendiam comer a carne do individuo visado.

Ainda, em publicação de 1833, em um mapa da capitania de Minas Gerais, elaborado por Eschwege, vê-se assinalado na região do Rio Doce: Distrito dos Índios Botocudos Antropófagos.

$\mathrm{Na}$ realidade, sob a denominação genérica de Botocudos, encontravam-se vários grupos indígenas os quais, como se vê, continuavam classificados como antropófagos, até pelo menos nos anos da Regência, isto é, já quase em meados do século XIX.

Lucy Maffei Hutter

O padre Caetano da Fonseca Vasconcelos vigário colado na Igreja de S. Miguel do Piracicaba do Distrito de Vila Nova da Rainha da Capitania de Minas Gerais não obstante achar-se em idade avançada, e com grave enfermidade crônica se viu constituído em duas extremas necessidades ambas veementes de viajar 
os centos de léguas incômodas e perigosas de terra e mar, que medeam até esta Corte: uma de fugir a toda a pressa da Morte eminente, com que o ameaçava a mesma enfermidade incurável no seu País, e só suposta remediável nas Caldas deste Reino, sobre cuja necessária licença autorizada tem o Suplicante requerimento pendente para ante a Pia e Benéfica Caridade de Vossa Alteza Real: e outra de renovar e promover as tristes memórias, que devem ter sido repetidas em ofícios dos governadores da mesma Capitania perante o Trono de Vossa Alteza Real, sobre os estragos horrorosos do Gentio bravo antropófago da nação Botocudo, que infesta, rouba, despedaça e come as carnes próprias dos Corpos dos Miseráveis Fregueses do Suplicante que procura encontrar.Ah, Senhor, que Cena tristíssima é, quando chegam carradas de Membros de Corpos humanos em montão truncados e descarnados enterrar na Freguesia do Suplicante; ficando o sangue, por delícia brutal, chupado das veias dos Miseráveis e as carnes comidas por aqueles Bárbaros? A última crueldade acontecida oferece o Suplicante no mal desenhado prospecto junto para avivar a Memória dele. Nos fins mais remotos da Freguesia já estão desertas léguas de fazendas; extinta a sua população e suspensa em conseqüência a utilidade pública na concorrência dos frutos respectivos; assim como suspensos o [sic] interesses que deles se deduziam para a Fazenda Real; mas os dízimos do resto da muito extensa Freguesia e os direitos dela ainda atualmente fazem uma importância tal, que sendo em protegêla dos ditos Bárbaros deve em poucos anos tornar cultiváveis as ditas léguas de terra, e propagar além delas a cultura com avanço do público e da mesma Real Fazenda. Isto assim foi com todo o acordo e fundamento bem entendido pelo governador Visconde de Barbacena quando multiplicou os Sítios dos presídios armados contra o dito bravo Gentio: o seu sucessor porém suspendendo os ditos presídios aumentou o atrevimento e crueldade dos ditos Bárbaros, mas no decurso de tāo lastimável desamparo foi Deus servido ilustrar o recto entendimento de Vossa Alteza Real, mandando presidir aquela Capitania o atual governador Pedro Maria Xavier de Ataide e Melo,o qual tomando na devida consideração de piedade Cristã de zelo pelo bom serviço de Vossa Alteza Real, e de proteção e utilidade daqueles Vassalos, este o objecto tão digno de providência, inflamado no bem público espiritual e temporal tomou sobre si, e até sobre os recursos da sua própria casa quando superiormente lhe não fosse aprovado, o renovar e estabelecer alguns presídios armados, é certo que por essas partes existe esse interino $e$ dependente remédio. Porém, Senhor, quepode fazer vantajoso e permanente um governador ainda que zeloso e melhor servidor se não for autorizado por Vossa Alteza Real. Necessita-se por isso de confirmar os poucos presídios que existem e multiplicá-los conforme a precisāo; e poderá ser que os próprios direitos e rendimentos Régios dos distritos infestados cheguem a pagar as despesas necessárias; resultando destas providências as povoaçōes das fazendas desertas, a sua multiplicação de frutos e em conseqüência o interesse público e o maior interesse da 
Fazenda Real. Roga por isso o Suplicante prostrado aos Reais Pés de Vossa Alteza Real vertendo lágrimas de amargura, de Caridade e de humanidade pelos seus desgraçados Fregueses, dignos Vassalos de Vossa Alteza Real se digne tomar este objecto em consideração de Justiça e de Caridade: e portantoPara Vossa Alteza Real seja servido em conseqüência deferir a justa representação do Suplicante com a benevolência, graça $e$ justiça, que the parecer mais própria para necessários justos fins pretendidos.[as.]Caetano d'Affonseca Vasconcelos.E Receberá Mercê.

Transcriçāo: Yêdda Dias Lima 